\title{
Production and biochemical characterization of xylanases synthesized by the thermophilic fungus Rasamsonia emersonii S10 by solid-state cultivation
}

Jéssica de Araujo Zanoni ${ }^{1}$, Isabela Brunozi de Oliveira $^{1} \oplus$, Olavo Micali Perrone ${ }^{1} \oplus$, Julieth Orduña Ortega ${ }^{2}{ }^{\oplus}$, Maurício Boscolo ${ }^{1}$, Eleni Gomes ${ }^{1} \oplus^{\infty}$, Gustavo Orlando Bonilla-Rodriguez $^{1+}{ }^{+}$

1. São Paulo State University, Institute of Biosciences, Languages and Exact Sciences, São José do Rio Preto, Brazil.

2. Universidad Santiago de Cali, Facultad de Ciencias Basicas, Cali, Colombia.

+Corresponding author: Gustavo Orlando Bonilla Rodriguez, Phone: +55 17 3221-2361, Email address: gustavo.b.rodriguez@unesp.br

\section{ARTICLE INFO}

Article history:

Received: July 03, 2020

Accepted: November 11, 2020

Published: April xx, 2021

\section{Keywords}

1. Endoxylanases

2. Thermostability

3. Sugarcane bagasse

4. Thermophilic fungus

5. Solid-state cultivation

ABSTRACT: The xylanolytic enzyme complex hydrolyzes xylan, and these enzymes have various industrial applications. The goal of this work was to characterize the endoxylanases produced by the thermophilic fungus Rasamsonia emersonii in solid-state cultivation. Tests were carried out to evaluate the effects of $\mathrm{pH}$, temperature, glycerol and phenolic compounds on enzyme activity. Thermal denaturation of one isolated enzyme was evaluated. The crude extract from $R$. emersonii was applied to breakdown pretreated sugarcane bagasse, by quantifying the release of xylose and glucose. The optimum $\mathrm{pH}$ value for the crude enzymatic extract was 5.5 , and $80{ }^{\circ} \mathrm{C}$ was the optimum temperature. Regarding the stability of the crude extract, the highest values occurred between the $\mathrm{pH}$ ranges from 4 to 5.5 . Several phenolic compounds were tested, showing an increase in enzymatic activity on the crude extract, except for tannic acid. Zymography displayed four corresponding endoxylanase bands, which were isolated by extraction from a polyacrylamide gel. The thermodynamic parameters of isolated Xylanase $\mathrm{C}$ were evaluated, showing a half-life greater than $6 \mathrm{~h}$ at $80{ }^{\circ} \mathrm{C}$ (optimum temperature), in addition to high melting temperature $\left(93.3{ }^{\circ} \mathrm{C}\right)$ and structural resistance to thermal denaturation. Pretreated sugarcane bagasse breakdown by the crude enzymatic extract from $R$. emersonii has good hemicellulose conversion to xylose.

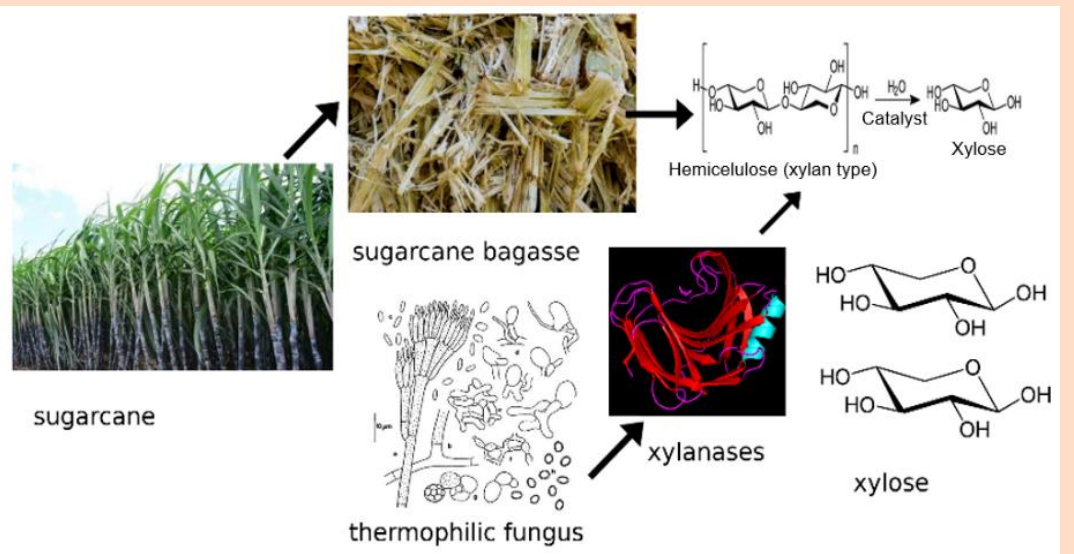

Hemicellulose enzymatic bioconversion by endoxylanases from fungus 


\section{Introduction}

The negative effects resulting from the growing demand for fossil fuel energy have mobilized the international community in the search for renewable fuels ${ }^{1,2}$. An alternative is the use of biofuels, and, among them bioethanol, or second-generation ethanol $(2 \mathrm{G})$, obtained by the fermentation of sugars present in plant residues ${ }^{3,4}$.

The plant cell wall matrix is lignocellulosic and composed of cellulose fibrils with a protective layer of hemicellulose and lignin. Covalent bonds ensure cell wall rigidity and high resistance to microbial degradation $^{5}$. Cellulose is the primary constituent ${ }^{6}$, followed by hemicellulose, which is composed by different linked monomers, resulting in a branched heteropolysaccharide. These monomers include pentoses (D-xylose, L-arabinopyranose, Larabinofuranose), hexoses (D-glucose, D-mannose, Dgalactose), hexuronic acids (D-glycuronic, D-4-Omethylglycuronic, D-galacturonic) and deoxyhexoses (L-rhamnose and L-fucose) ${ }^{7}$. Xylan, a polymer of Dxylose, is the primary polymer constituent of hemicelluloses.

Xylanases degrade xylan by hydrolyzing the $\beta 1,4$ glycosidic bonds producing xylooligosaccharides (XOS) and $\beta$-xylosidases convert them to xylose. However, xylan has more structural complexity, containing $\beta$-D-xylopyranoside residues linked by $\beta 1,4$ glycosidic bonds associated with other sugars, forming glucuronoxylans, glucuronoarabinoxylans, glucomannans, arabinogalactans and galactoglucomannans ${ }^{8}$. Because of this heterogeneity, their complete hydrolysis requires several enzymes acting synergistically to convert their disaccharides and constituent monosaccharides into its subunits ${ }^{9,10}$.

Industry uses enzymes of the xylanolytic complex in different processes. For example, the paper industry uses enzymes in the bleaching stage to replace chlorine, as they promote the removal of xylan linked to the lignin, facilitating the bleaching of lignin ${ }^{11}$. They are also used in the pretreatment of arabinoxylan found in the substrate in beer production, reducing the viscosity and facilitating the process of filtration. These enzymes are employed in the production of bread, by increasing the volume of the product, making the dough soft and loose $\mathrm{e}^{12}$.

Filamentous fungi are the major producers of enzymes of the xylanolytic complex, followed by macromycetes, bacteria, seaweed and some germinating plant seeds ${ }^{8}$. Fungal enzymes for biotechnological purposes can be produced in two main ways: by cultivation in solid-state (CSS) or by submerged culture $(\mathrm{CSm})$. The CSm is characterized by the high availability of free water in the culture medium $^{13}$. To promote the aeration necessary for the growth of filamentous fungi, it is necessary to agitate the culture medium, but the constant agitation during the growth of the mycelium can cause morphological changes in the microorganism ${ }^{14}$, resulting in changes in the metabolite production.

Cultivation in solid-state is carried out without the presence of free water, and with the humidity necessary for fungal growth ${ }^{15}$, the material is incubated and the product is recovered at the end of the process. The solid substrate provides better conditions for mycelial growth and is similar to the natural environment of fungi, requiring a lower demand of energy $^{16}$. Aeration of the medium does not require agitation when the fungus contact surface with the substrate is assured.

The biodegradation of xylan by enzymes from the xylanolytic complex allows to obtain several products, such as xylitol, xylooligosaccharides (XOS) and xylose $^{8,17}$. In recent years, the use of these enzymes in saccharification of plant biomass has gained prominence, since in combination with other enzymes they facilitate the release of monosaccharides from the hemicellulose polymer, thus, yeasts can metabolize them for the production of second generation ethanol ${ }^{4}$. The enzymatic attack on the lignocellulosic material allows the conversion of polymers into carbohydrate monomers. For an efficient degradation, it is necessary to overcome the structural barrier of this material, and for that pretreatment strategies are adopted. Several options can be used; the main ones are physical, chemical and biological pretreatment. Also, the combination of these processes is described as more efficient in removing the noncellulosic fraction ${ }^{18}$.

Physical pretreatment (grinding, radiation, or heat treatment) is responsible for decreasing polymerization of the material, increasing the surface area. Among thermal methods, high temperatures are required, the biomass is mixed with water and are heated to the desired temperature and held at the pretreatment conditions for a controlled time before being cooled ${ }^{19}$. Higher temperatures require shorter treatment times, while lower temperatures require longer treatment times. In this context, it would be helpful to use thermostable enzymes for the next hydrolysis step, thus, the pretreated material could be hydrolyzed at high temperatures, saving refrigeration resources.

This study describes a biochemical characterization of endoxylanases from the crude extract of the thermophilic fungi Rasamsonia emersonii. In addition, it was investigated the effectiveness of this crude 
extract to hydrolyze pretreated sugarcane bagasse to release products, like glucose and xylose. Endoxylanases isolation and the analysis of thermostability for the enzyme with the highest activity towards xylan were also carried out.

\section{Experimental}

\subsection{Materials}

All chemicals and solvents used for the procedures were analytical grade.

\subsection{Enzyme production by $R$. emersonii S10 by solid-state cultivation}

The thermophilic fungus $R$. emersonii $\mathrm{S} 10$, isolated and identified by a previous work ${ }^{20}$, was cultivated on Sabouraud dextrose agar. From this agar, 20 disks of $1 \mathrm{~cm}$ in diameter were extracted and cultivated at $55^{\circ} \mathrm{C}$ for 6 days in individual polypropylene bags containing $5 \mathrm{~g}(1: 1: 1 \mathrm{w} / \mathrm{w})$ of sugarcane bagasse, wheat bran and corn straw, these were previously washed on distilled water and dried at $47{ }^{\circ} \mathrm{C}$ until constant weight. To each bag were added $20 \mathrm{~mL}$ of nutrition solution $\left(3.5 \mathrm{~g} \mathrm{~L}^{-1}\right.$ of $(\mathrm{NH})_{4} \mathrm{SO}_{4}, 3 \mathrm{~g} \mathrm{~L}^{-1}$ of $\mathrm{KH}_{2} \mathrm{PO}_{4}, 0.5 \mathrm{~g} \mathrm{~L}^{-1}$ of $\mathrm{CaCl}_{2}$, $0.5 \mathrm{~g} \mathrm{~L}^{-1}$ of $\mathrm{MgSO}_{4-7} 7 \mathrm{H}_{2} \mathrm{O}$ and $10 \mathrm{~g} \mathrm{~L}^{-1}$ of tween 80) at pH 5.0.

To prepare the enzyme extract, $50 \mathrm{~mL}$ of deionized water was added, and the plastic bags were placed on an orbital shaker at $150 \mathrm{rpm}$ for $40 \mathrm{~min}$. The liquid extract containing the enzymes was transferred from the bag and it was vacuum filtered through a $0.45 \mu \mathrm{m}$ nylon membrane. Subsequently, the filtrate was centrifuged at $10,000 \mathrm{xg}$ for $30 \mathrm{~min}$ at $4{ }^{\circ} \mathrm{C}$. The supernatant was the used as crude extract in the subsequent procedures.

\subsection{Biochemical characterization of xylanases from the crude extract}

To determine the xylanolytic activity, the sample was incubated in $1 \%(\mathrm{w} / \mathrm{v})$ beechwood xylan at $55^{\circ} \mathrm{C}$ for $10 \mathrm{~min}$, and for endoglucanase activity, the sample was incubated with $4 \% \quad(\mathrm{w} / \mathrm{v})$ of carboxymethylcellulose (CMC) as substrate at $50{ }^{\circ} \mathrm{C}$ using a 1:9 enzyme:substrate volume ratio ${ }^{21}$. The released reducing sugars reacted with 3,5dinitrosalicylic acid (DNS) and the activity was quantified using spectrophotometry, being expressed as the product concentration change over time $(\mathrm{d}[\mathrm{P}] / \mathrm{dt})^{22}$, which was linear up to $4 \mathrm{~min}$, time adopted for the enzymatic assays. Experiments were carried out using a $0.1 \mathrm{~mol} \mathrm{~L}^{-1}$ acetate buffer $\mathrm{pH} 5.5$, with the exception of the determination of the optimal $\mathrm{pH}$.

All experiments to determine the optimal $\mathrm{pH}(3.0$ 9.5) and temperature $\left(30-90{ }^{\circ} \mathrm{C}\right)$ were conducted in three repetitions, and the $\mathrm{pH}$ stability of the crude extract was evaluated after $24 \mathrm{~h}$ of incubation in this range of $\mathrm{pH}$, at the optimum temperature. For the optimal $\mathrm{pH}$ determination, the following buffers $\left(0.1 \mathrm{~mol} \mathrm{~L}^{-1}\right)$ were used: citrate $(\mathrm{pH} 3.0$ and 3.5$)$, acetate $(\mathrm{pH} 4,4.5,5.0$ and 5.5), MES (pH 6.0, 6.5 and 7.0), tris $(\mathrm{pH} 7.5$ and 8.0) and glycine $(\mathrm{pH} 8.5,9.0$ and 9.5). For the $\mathrm{pH}$ stability experiment, the enzyme activity was expressed as the relative activity between the activity before and after the $24 \mathrm{~h}$ treatment.

The effect of glycerol on the storage conditions of the xylanases was evaluated by their activity, performing every experiment in triplicate. Three aliquots of the crude extract were stored in liquid nitrogen $\left(-196{ }^{\circ} \mathrm{C}\right),-80{ }^{\circ} \mathrm{C}$ freezer, freezer $\left(-20{ }^{\circ} \mathrm{C}\right)$, refrigerator $\left(4{ }^{\circ} \mathrm{C}\right)$ and room temperature $\left(25^{\circ} \mathrm{C}\right)$, with and without glycerol 50\% (v/v). The enzyme activity was quantified before and after $24 \mathrm{~h}$ of storage.

\subsection{Effect of phenolic compounds on the xylanolytic activity}

The inhibition of xylanolytic activity by phenolic compounds was tested on the crude extract at room temperature $\left(24{ }^{\circ} \mathrm{C}\right)$. The following compounds were tested individually at a final concentration of 10 mmol L ${ }^{-1}$ : tannic acid, p-coumaric acid, syringic acid, gallic acid, ferulic acid, 4-hydroxybenzoic acid, vanillin, vanillic acid and syringaldehyde. The enzymatic activity was measured and expressed as percentage for the solutions incubated for $10 \mathrm{~min}, 24$ and $48 \mathrm{~h}$. The activity of the enzyme was compared with that measured prior to incubation, considered to be $100 \%$.

\subsection{Sugarcane bagasse pretreatment}

The pretreatment was carried out by a combination of ozonolysis with an alkaline treatment ${ }^{23}$. After these procedures, the bagasse was either washed or left unwashed. The washed bagasse was rinsed several times with distilled water. Both washed and unwashed treated bagasses were dried in a convective oven at $40{ }^{\circ} \mathrm{C}$ until constant weight. 


\subsection{Enzymatic hydrolysis of sugarcane bagasse}

Hydrolysis was performed using an orbital shaker at $150 \mathrm{rpm}$ in glass flasks with rubber stoppers, containing $0.5 \mathrm{~g}$ of washed or unwashed bagasses, $2.5 \mathrm{~mL}$ of acetate buffer $0.1 \mathrm{mmol} \mathrm{L}^{-1} \mathrm{pH} 5.5$ and $2.5 \mathrm{~mL}$ of crude extract of $R$. emersonii containing $22 \mathrm{U} \mathrm{mL} \mathrm{m}^{-1}$ of xylanase (or $110 \mathrm{U}$ per $\mathrm{g}$ of sugarcane bagasse) and $17 \mathrm{U} \mathrm{mL}^{-1}$ of endoglucanases (or $85 \mathrm{U}$ per $\mathrm{g}$ of sugarcane bagasse). All the tests were conducted in three repetitions.

A preliminary test to determine the optimal time and temperature for enzymatic hydrolysis was conducted with untreated sugarcane bagasse. The untreated sugarcane bagasse was hydrolyzed for 6,12 and $24 \mathrm{~h}$ at 50,60, 70 and $80{ }^{\circ} \mathrm{C}$. Maximum hydrolysis was observed with $6 \mathrm{~h}$ at $60^{\circ} \mathrm{C}$.

The pretreated sugarcane bagasses, washed and unwashed, were hydrolyzed at $60{ }^{\circ} \mathrm{C}$ for 2,4 and $6 \mathrm{~h}$. The material was filtered after hydrolysis, and the soluble fraction was used for quantification of released sugars. Experiments were performed using sugarcane bagasse (untreated, washed and unwashed pretreated) with $5 \mathrm{~mL}$ of $0.1 \mathrm{mmol} \mathrm{L}^{-1} \mathrm{pH} 5.5$ acetate buffer (without enzyme extract) as a control of hydrolysis.

The efficiency in converting hemicellulose (or cellulose) was calculated as in Eq. 1:

$\%$ xylose $=\frac{\mathrm{c} \times \mathrm{v} \times 0.9}{\mathrm{~m}} \times 100 \%$

where $\mathrm{c}$ is the concentration $\left(\mathrm{g} \mathrm{L}^{-1}\right)$ of sugars in the soluble fraction hydrolyzed, $\mathrm{v}$ is the volume in liters of soluble fraction and $\mathrm{m}$ is the hemicellulose (or cellulose) mass in grams.

\subsection{Quantification of the sugars from the breakdown of the sugarcane bagasse}

The procedures were done according to Perrone et al. ${ }^{23}$. The obtained hydrolysates from washed and unwashed pretreated sugarcane bagasses were analyzed by chromatography. The quantification of glucose and xylose were carried out using highperformance liquid chromatography (HPLC) with a pulsed amperometric detector (HPAEC-PAD, Thermo Scientific, Dionex, ICS-5000). A Dionex CarboPac PA-1 column was used for separation at $25^{\circ} \mathrm{C}$, using a flow of $1 \mathrm{~mL} \mathrm{~min}{ }^{-1}$ with ultrapure water (solvent A) and $0.5 \mathrm{~mol} \mathrm{~L}^{-1} \mathrm{NaOH}$ (solvent B). Elution was carried from 0 to 12 min with $4.8 \%$ of solvent $\mathrm{B}$, and from 12 to 16 min with $100 \%$ of the same solution. Before each injection, the sample was diluted and filtered through a
$0.22 \mu \mathrm{m}$ polyvinylidene fluoride (PVDF) filter unit (Merck).

\subsection{Electrophoretic profile of endoxylanases produced by $R$. emersonii}

Polyacrylamide gel electrophoresis was performed on the crude extract. The gel was immersed on $1 \%$ of triton X-100 at the end of the run to eliminate the residual SDS and washed with a $0.1 \mathrm{mmol} \mathrm{L}^{-1} \mathrm{pH} 5.5$ acetate buffer.

One vertical strip was separated and used for zymogram analysis ${ }^{24}$. After that, the strip and the original unstained gel were put side by side and a strip of the gel was cut horizontally to compare the known gel isoforms with the zymogram, a technique used to isolate other enzymes ${ }^{25}$.

The enzymatic activity of the four isolated endoxylanase isoforms was analyzed against different substrates: the synthetic substrates pNPG (specific for $\beta$-xylanases) and pNPX (specific for $\beta$-glucanases), and the natural polymers CMC (for endoglucanases), beechwood xylan and oat spelt xylan (for endoxylanases).

\subsection{Thermodynamic analysis of $X y l_{-} C$ isolated from the crude enzymatic extract of $R$. emersonii}

Among the four isolated isoforms, was selected the xylanase that showed the highest affinity for the complex substrate, confirming the endoxylanase identity for these experiments.

The thermodynamic analysis of Xyl_C thermal denaturation was done using xylan from beechwood at the optimum $\mathrm{pH}$. After incubation at each temperature samples were cooled in ice overnight, followed by the enzyme assay for residual activity. The calculation of the activation energy $E_{\mathrm{a}}$, the temperature coefficient $Q_{10}$, half-life $T_{1 / 2}$ and other parameters of the enzyme related to the thermal denaturation, including the activation energy $E_{\mathrm{a}(\mathrm{D})}$, melting temperature $T_{\mathrm{m}}, \Delta H_{(\mathrm{D})}$, $\Delta G_{(\mathrm{D})}$ and $\Delta S_{(\mathrm{D})}$, followed the method proposed in the literature ${ }^{26,27}$ and done in previous studies with other enzymes ${ }^{28,29}$. The irreversible denatured "I" state is evaluated using the model $\mathrm{N} \leftrightarrow \mathrm{D} \rightarrow \mathrm{I}$, where $\mathrm{N}$ represents the native conformation and $\mathrm{D}$ the reversible denatured conformation. 


\section{Results and discussion}

\subsection{Production and biochemical characterization of endoxylanases on the crude extract produced by $R$. emersonii}

The production of endoxylanases by $R$. emersonii on solid state cultivation was $473.86 \mathrm{U} \mathrm{g}^{-1}$ after $144 \mathrm{~h}$ of cultivation at $55{ }^{\circ} \mathrm{C}$. The substrate combination of equal amounts of sugarcane bagasse, wheat bran, and corn straw $(\mathrm{w} / \mathrm{w})$ results on a complex carbon source. The protein expression changes, as recorded for $R$. emersonii, with different culture media. This fact can be a mechanism directly or indirectly based on the accumulation in the medium of the products and substrates on which the enzymes are working and which will influence their induction ${ }^{30}$.

When analyzing the chemical composition of substrates used to induce xylanase production, it could be inferred that the combination of various substrates, such as sugarcane bagasse, corn straw; and wheat bran, is successful due to the heterogeneity of the composition to which the fungus was subjected. Corn straw has higher xylan values than the stalk of the plant, with $26.8 \%$ xylan in the straw versus $19.4 \%$ xylan in the stalk. In contrast, proteins constitute $1.2 \%$ in the fiber and $3.4 \%$ in the stem ${ }^{31}$. Sugarcane bagasse has a characteristic chemical composition that is high in cellulose, hemicellulose and lignin, while overall ash values are lower $(1.0-5.5 \%)^{32}$, factors that make it attractive for the cultivation of microorganisms that produce lignocellulolytic enzymes. Studies use wheat bran as a substratum for the production of biomass because it is rich in starch; however, the oligosaccharides present in its composition are shown to be efficient in inducing cellulase and hemicellulase production $^{33}$.

The optimum $\mathrm{pH}$ and temperature of xylanases on the crude enzymatic extract from $R$. emersonii was 5.5 (Fig. 1) and $80{ }^{\circ} \mathrm{C}$ (Fig. 2), close to those described for Talaromyces emersonii, currently classified as R. emersonii, with solid-state wheat and beet pulp cultivation $(1: 1 \mathrm{w} / \mathrm{w})$ at $\mathrm{pH} 4.5$ and $45{ }^{\circ} \mathrm{C}^{30}$. Another increase of activity occurred at $\mathrm{pH} 7.0$ and suggests isoforms of the endoxylanases produced by R. emersonii, since the zymogram shown in Fig. 3 indicates four bands.

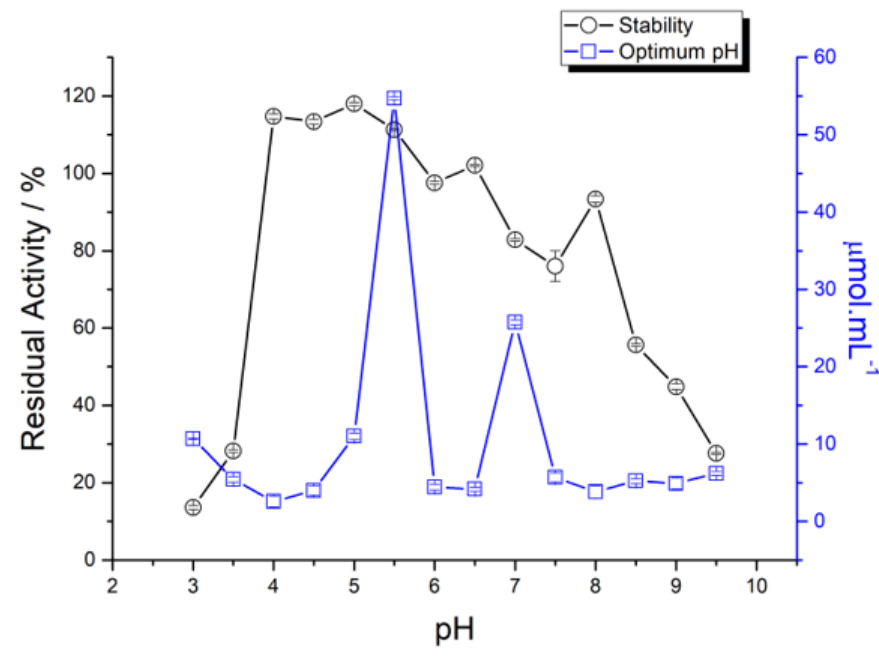

Figure 1. Effect of $\mathrm{pH}$ on xylanolytic activity in crude enzymatic extract produced by $R$. emersonii. Stability in relation to $\mathrm{pH}$ and optimum $\mathrm{pH}$. The tests were performed at $\mathrm{pH} 5.5$ with beechwood xylan. The symbol represents the average of three replicates.

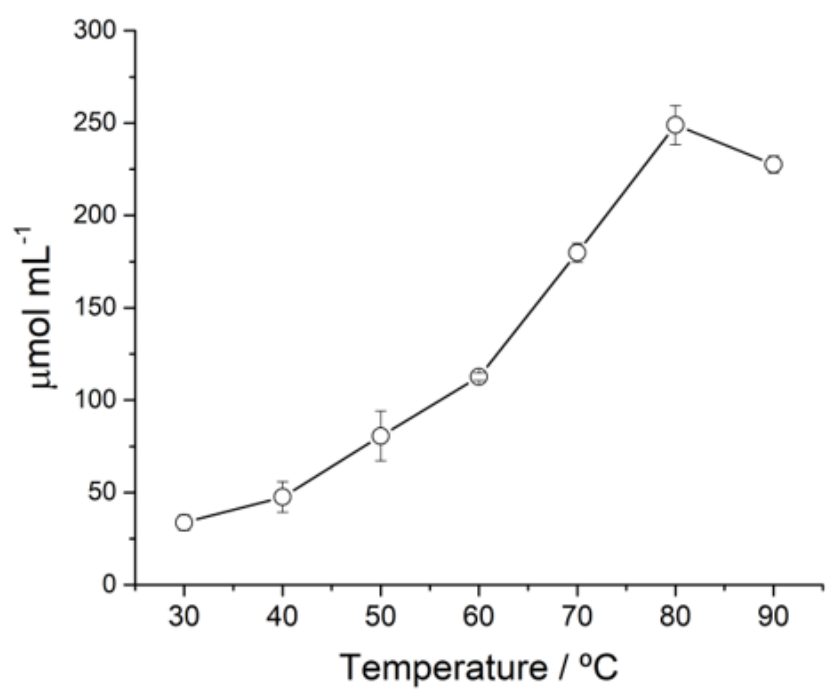

Figure 2. Effect of incubation temperature on xylanolytic activity from crude enzymatic extract produced by the thermophilic fungus $R$. emersonii. The tests were performed at $\mathrm{pH} 5.5$ with beechwood xylan. The symbol represents the average of three replicates. 


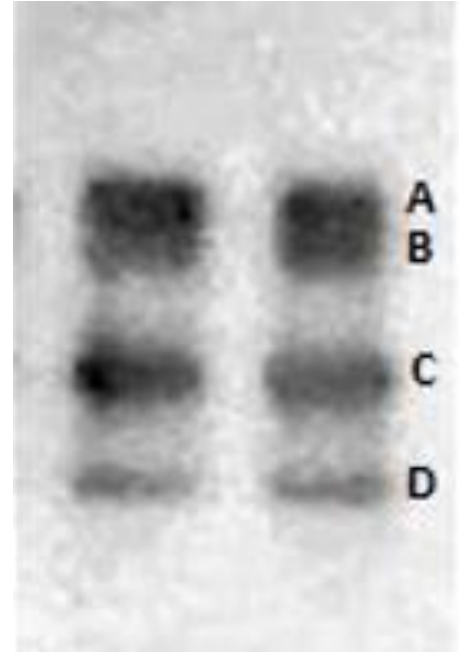

Figure 3. Zymogram of endoxylanases present from crude enzymatic extract produced by the fungus $R$. emersonii. The gel was stained with $0.1 \%$ congo red and detained with $1 \mathrm{~mol} \mathrm{~L}^{-1} \mathrm{NaCl}$. The dark bands show the presence of xylanase and the letters (A, B, C and $\mathrm{D})$ identify the possible isoforms of the enzyme (the image was transformed from color to shades of gray, then into its negative and the contrast became more evident using the free software GIMP version 2.8.10 for Linux).

Endoxylanolytic activity remained stable for $\mathrm{pH}$ ranging from 4 to 8 , with relative activity above $70 \%$, and from 4 to 5.5 with relative activity values above $100 \%$ (Fig. 1). The chemical species related to the $\mathrm{pH}$ can change the tridimensional structure of the enzyme, by protonation or deprotonation of the amino acid side chains on the enzyme surface or affecting the catalytic residues, becoming more favorable or unfavorable to interact with the substrate. Among these changes, electrostatic repulsions, destruction of salt bridges and formation of isolated buried charges stand out ${ }^{34}$.

Comparative analyses of structural changes in acid, neutral and alkaline xylanases from family 11 shows differences in the amino acid compositions and secondary structure. Neutral xylanases have a decrease on hydrophobic residues, while acidophilic xylanases have a decrease on positively charged residues. On the secondary structure, alkaline xylanases show an $\alpha$ helix between $\beta$ strands, and, in nonalkaline xylanases, this is substituted by a $\beta$-turn or a loop ${ }^{35}$.

In the absence and presence of glycerol, the two best storage conditions were obtained in liquid nitrogen at $-196{ }^{\circ} \mathrm{C}$ with $99 \%$ relative activity in the absence and $170 \%$ in the presence of $50 \%$ glycerol, and in a $80{ }^{\circ} \mathrm{C}$ freezer, which kept $90.2 \%$ of activity in the absence and $163.8 \%$ in the presence of $50 \%$ glycerol (Fig. 4).

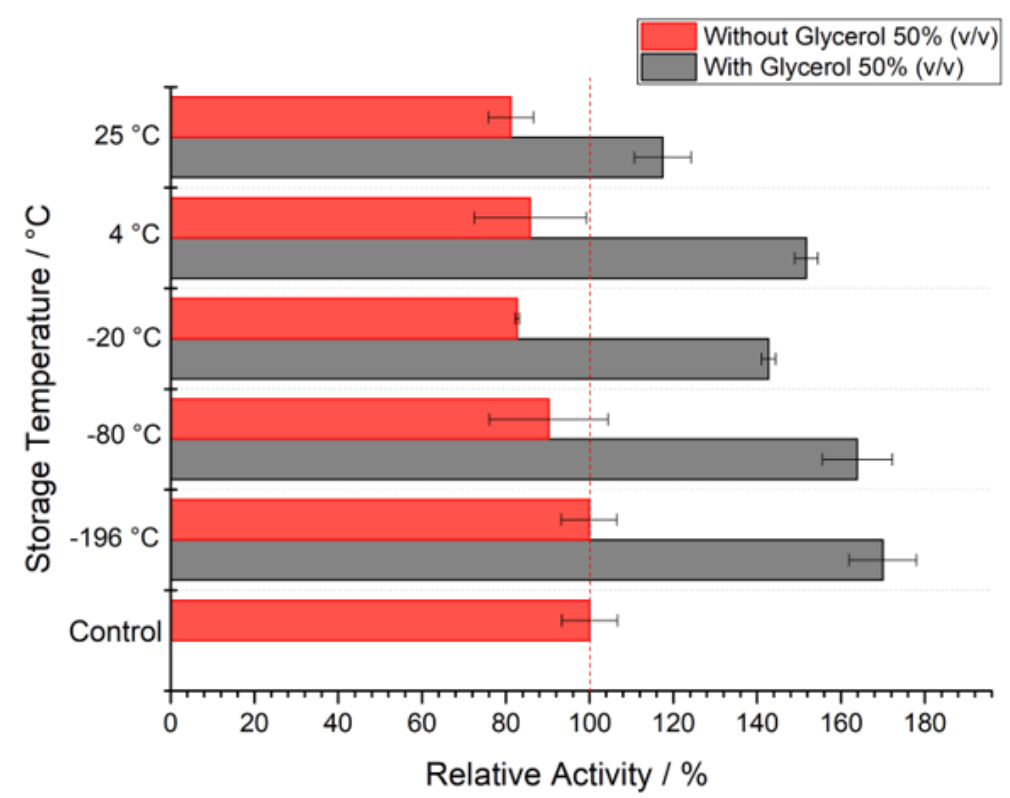

Figure 4. Effect of the storage temperature on the enzymatic activity of endoxylanases present in the crude enzymatic extract produced by $R$. emersonii. The tests were carried out after $24 \mathrm{~h}$ in the presence or in the absence of $50 \%$ glycerol $(\mathrm{v} / \mathrm{v})$. The results were compared with the enzymatic activity at the beginning of the experiment (control) and expressed in relative activity (\%). The bar represents the value of the average of three replicates, the horizontal line represents the standard deviation. 
The presence of glycerol during the storage process increased the endoxylanase activity on all the tested conditions. The effect of osmolytes on the conformational stability of proteins in adverse situations of cellular stress is known ${ }^{36}$. Similarly to sorbitol, it favors protein folding, making the polypeptide chain more compact and less flexible, since it acts by shifting the reaction balance to the less energetic state ${ }^{37}$.

The interaction of the enzyme with the osmolyte is not favorable for its function, so it is excluded from the surface of the protein, where a hydration layer is formed by several highly organized and less flexible water layers. Consequently, the unfolded state has a greater contact surface of the polypeptide chain with water molecules, resulting in a larger hydration layer, which will require more energy for stabilization. For this reason, glycerol acts by shifting the reaction balance towards the native state, increasing levels of enzyme catalytic effect ${ }^{38}$.

\subsection{Effect of phenolic compounds on the xylanolytic activity on the crude extract from $R$. emersonii}

From all the tested phenolics (Fig. 5), the only one that decreased the xylanolytic activity was tannic acid, a large molecule with a molecular weight of $1,701.23 \mathrm{kDa}$, which is composed by 10 aromatic rings and 25 hydroxyls, characteristic that could explain the inactivation of the endoxylanolytic activity, according to observations previously cited ${ }^{39}$. Tannins can form a complex with the protein that results in precipitation, thus, the enzyme is removed from the solution, decreasing its catalytic capacity ${ }^{40,41}$.

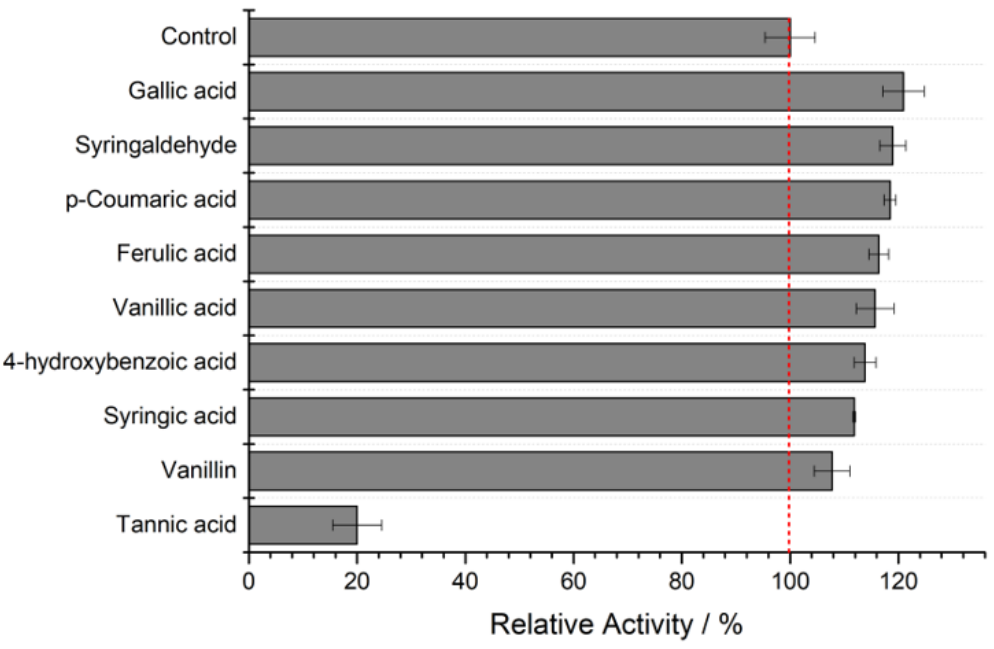

Figure 5. Effect of $48 \mathrm{~h}$ preincubation at $25{ }^{\circ} \mathrm{C}$ of phenolic compounds on the relative activity (\%) of endoxylanases on crude extract produced by $R$. emersonii. The bar represents the value of the average of three replicates, the horizontal line represents the standard deviation.

The other compounds analyzed showed a modest or a significant increase of the relative activity compared to the control. The relative activity of the enzymes increased $12 \%$ for 4-hydroxybenzoic acid; $16 \%$ for vanillic acid; $26 \%$ for ferulic acid and $44 \%$ for syringic acid in a $30 \mathrm{mmol} \mathrm{L}^{-1}$ final concentration ${ }^{42}$.

Phenolic compounds are generated from lignin degradation $^{43}$ during the pretreatment step of the biomass aiming second generation ethanol production and are reported as enzymatic inhibitors ${ }^{44,45}$ including hemicellulase inhibition ${ }^{46}$. Some authors propose that phenolic acids at low concentrations can form a hydrophobic layer on the surface of the protein, ensuring more interaction with the substrate; however, at high concentrations the increase in this hydrophobic layer causes protein precipitation due to increased interactions $s^{41,42,47}$. Boukari et al. $^{39}$ proposed the inhibition mechanism by phenolic compounds on

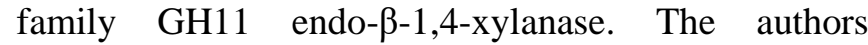
described a noncompetitive inhibition mechanism, and more than one aromatic molecule interacting with the enzyme molecule is necessary to induce complete inactivation. Effects on the enzyme activity by the phenolic compound interaction can be produced by forming soluble enzyme-inhibitor complex at low phenolic concentrations, while, at high concentrations, insoluble protein-phenolic complexes decrease the solubility of enzymes ${ }^{45}$. 
The interaction of phenolic compounds with proteins involve amino acid residues present at the surface of the protein, and can occur in two ways: hydrophobic aromatic ring stacking with the tryptophan side chains, or hydrogen interacting with basic amino acid residues between their functional groups and phenolic hydroxyl ${ }^{39}$.

\subsection{Enzymatic hydrolysis of pretreated sugarcane bagasse}

The quantification of xylose was slightly higher in the washed sugarcane bagasse when compared to the nonwashed, in all evaluations, which difference increased with time. In hydrolysis for six hours, the xylose concentration was almost 1.5 times higher with washed sugarcane bagasse than with the unwashed one (Tab. 1). Glucose release presented a similar behavior.

Concentration of hemicellulose $(14.1 \%)$ and cellulose $(48.9 \%)$ on the insoluble fraction after the

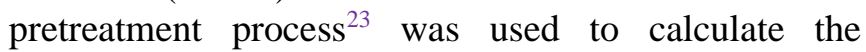
hydrolysis efficiency in terms of xylose and glucose. Under all analyzed conditions, the conversion of xylose was greater than glucose (Tab. 1), presumably due to high xylanolytic activity in the $R$. emersonii crude enzymatic extract, and pretreated bagasse structural changes, that could affect cellulose and hemicellulose accessibility. The conversion of xylose was greater than glucose under all the analyzed conditions (Tab. 1), suggesting that the crude enzymatic extract from $R$. emersonii has many xylanolytic enzymes. However, auxiliary enzymes are necessary to have a greater effect on the breakdown of the xylan structure and make cellulose more accessible to hydrolysis ${ }^{48}$. Analysis of the secretome of T. emersonii shows 266 proteins, and 119 CAZymes identified with 40 different glycosyl hydrolase families, while the functional annotation of fungi genome shows represent 55 different glycosyl hydrolase families ${ }^{49}$. The secretion of protein by fungi relate directly to the carbon source used for fungi cultivation, so analyses of different complex carbon sources on the culture medium of $R$. emersonii can be performed to find how to improve the expression of enzymes for xylan hydrolysis.

Table 1. Sugars obtained by enzymatic hydrolysis of pretreated sugarcane bagasse with combined ozone and alkaline treatment, using crude enzymatic extract produced by $R$. emersonii.

\begin{tabular}{|c|c|c|c|c|}
\hline \multicolumn{5}{|c|}{ Xylose } \\
\hline $\begin{array}{l}\text { Hydrolysis } \\
\text { time / h }\end{array}$ & $\begin{array}{l}\text { Washed bagasse / } \\
\mathrm{mg} \mathrm{g}^{-1}\end{array}$ & $\begin{array}{l}\text { Yield washed bagasse / } \\
\% \mathrm{~g}^{-1}\end{array}$ & $\begin{array}{l}\text { Unwashed bagasse / } \\
\mathrm{mg} \mathrm{g}^{-1}\end{array}$ & $\begin{array}{l}\text { Yield unwashed bagasse / } \\
\qquad \% \mathrm{~g}^{-1}\end{array}$ \\
\hline 2 & $5.8 \pm 0.3$ & $3.7 \pm 0.2$ & $4.9 \pm 0.3$ & $3.1 \pm 0.5$ \\
\hline 4 & $7.9 \pm 0.3$ & $5.0 \pm 1.2$ & $6.4 \pm 0.6$ & $4.1 \pm 0.4$ \\
\hline 6 & $12.4 \pm 1.0$ & $7.9 \pm 0.6$ & $8.8 \pm 0.2$ & $5.6 \pm 0.5$ \\
\hline \multicolumn{5}{|c|}{ Glucose } \\
\hline $\begin{array}{l}\text { Hydrolysis } \\
\text { time / h }\end{array}$ & $\begin{array}{l}\text { Washed bagasse / } \\
\mathrm{mg} \mathrm{g}^{-1}\end{array}$ & $\begin{array}{l}\text { Yield washed bagasse / } \\
\% \mathrm{~g}^{-1}\end{array}$ & $\begin{array}{l}\text { Unwashed bagasse / } \\
\mathrm{mg} \mathrm{g}^{-1}\end{array}$ & $\begin{array}{l}\text { Yield unwashed bagasse / } \\
\qquad \mathrm{g}^{-1}\end{array}$ \\
\hline 2 & $6.4 \pm 0.3$ & $2.1 \pm 0.7$ & $5.3 \pm 0.2$ & $1.3 \pm 0.2$ \\
\hline 4 & $10.0 \pm 0.4$ & $1.7 \pm 0.6$ & $7.3 \pm 0.9$ & $1.3 \pm 0.1$ \\
\hline 6 & $13.7 \pm 0.6$ & $1.7 \pm 0.5$ & $7.4 \pm 0.2$ & $1.1 \pm 0.2$ \\
\hline
\end{tabular}

Average \pm standard deviation (mean values of three independent measurements).

As noted earlier, the findings obtained could also be related to the effects of pretreatment on the lignocellulosic material structure. The pretreatment used in this study was proposed by Perrone et al. ${ }^{23}$, where the authors reported that the combined pretreatment of ozone and $\mathrm{NaOH}$ results in a greater amount of hemicellulose, when compared to the combined pretreatment of ozone with $\mathrm{NaOH}$ and ultrasound irradiation, and smaller amounts of hemicellulose than the pretreatment using only ozone. Still, according to the same authors, the insoluble fraction after the pretreatment has $6.7 \mathrm{mg}$ of total phenolic compounds per gram of sugarcane bagasse.
Therefore, the phenolic compounds would be present in the pretreated unwashed sugarcane bagasse, which could negatively affect the enzymatic performance and result in a lower yield of released monosaccharides.

Although our results on the effect of phenolic compounds on endoxylanolytic activity are promising, with the only exception of tannic acid, there is a probability that negative results could be observed when several phenolic compounds are present in the same solution and submitted to higher temperatures.

The possible effect of $\mathrm{pH}$ resulting from the alkaline pretreatment was also considered, and, for that reason, it was performed an inhibition test with the soluble 
fraction obtained after that procedure. In this inhibition test, the crude enzyme extract was diluted in the same volume with the insoluble fraction resulting from the sugar cane bagasse pretreatment process. The mixture remained in contact for $0,2,4$ and $6 \mathrm{~h}$, and, after each time, endoxylanase activity was evaluated and compared with the values obtained before the test. The maximum value of inhibition of relative activity was $10 \%$ for the time of $2 \mathrm{~h}$, remaining essentially constant $(9.8 \%)$ in $4 \mathrm{~h}$ and decreasing to $8.2 \%$ after $6 \mathrm{~h}$. The $\mathrm{pH}$ was 6.1 after $2 \mathrm{~h}, 5.9$ at $4 \mathrm{~h}$ and 5.7 after $6 \mathrm{~h}$ for the unwashed bagasse, while the $\mathrm{pH}$ was 5.5 for the washed bagasse. A reason for the lower activity may be the higher $\mathrm{pH}$ in the unwashed bagasse, above the optimum verified at 5.5 .

Our hydrolysis results are similar to those presented by Marques et al. ${ }^{50}$. In their work, hydrothermally pretreated sugarcane bagasse was hydrolyzed using a mixture $(1: 1 \mathrm{v} / \mathrm{v})$ of the enzymatic extracts produced by solid-state cultivation of fungi Botryosphaeria sp. AM01 and Saccharicola sp. EJC04. In this case, pretreated bagasse hydrolysis continued at $50{ }^{\circ} \mathrm{C}$ for 20 $\mathrm{h}$ with an enzymatic load of $150 \mathrm{U} \mathrm{g}^{-1}$ of pretreated bagasse at $5 \%(\mathrm{~m} / \mathrm{v})$ concentration. The authors had $3.56 \mathrm{mg} \mathrm{mL}^{-1}$ of glucose and $1.66 \mathrm{mg} \mathrm{mL}^{-1}$ of xylose.
Our findings were $1.37 \mathrm{mg} \mathrm{mL} \mathrm{m}^{-1}$ of glucose and $1.24 \mathrm{mg} \mathrm{mL}^{-1}$ of xylose at $60{ }^{\circ} \mathrm{C}$, using approximately one third of the incubation time and a lower enzymatic load $\left(110 \mathrm{U} \mathrm{g}^{-1}\right)$.

Our results are similar to those presented by Marques and coworkers. In their work, hydrothermally pretreated sugarcane bagasse was hydrolyzed using a mixture $(1: 1 \mathrm{v} / \mathrm{v})$ of the enzymatic extracts produced by solid-state cultivation of fungi Botryosphaeria sp. AM01 and Saccharicola sp. EJC04. In this case, pretreated bagasse hydrolysis continued at $50{ }^{\circ} \mathrm{C}$ for 20 hours with an enzymatic load of $150 \mathrm{U} / \mathrm{g}$ of pretreated bagasse at $5 \%(\mathrm{~m} / \mathrm{v})$ concentration. The authors had $3.56 \mathrm{mg} / \mathrm{mL}$ of glucose and $1.66 \mathrm{mg} / \mathrm{mL}$ of xylose $^{50}$. Our findings were $1.37 \mathrm{mg} / \mathrm{mL}$ of glucose and $1.24 \mathrm{mg} / \mathrm{mL}$ of xylose at $60{ }^{\circ} \mathrm{C}$ using approximately one third of the incubation time and a lower enzymatic load $(110 \mathrm{U} / \mathrm{g})$. Table 2 shows more comparisons with the literature.

The lower sugar yields in the unwashed sugarcane bagasse could be the result of a sum of factors, such as the inhibitory effect of the residual alkaline $\mathrm{pH}$ of the pretreated bagasse that increased $\mathrm{pH}$ of the assay above the optimum value, and a potential inhibitory effect of a mixture of phenolic compounds.

Table 2. Comparative xylose and glucose conversion by enzymatic hydrolyze from sugarcane bagasse.

\begin{tabular}{|c|c|c|c|c|c|c|}
\hline Organism & $\begin{array}{c}\text { Hydrolysis } \\
\text { time / h }\end{array}$ & Tempe. $/{ }^{\circ} \mathrm{C}$ & $\begin{array}{c}\text { Sugarcane } \\
\text { bagasse } / \% \mathrm{~m} / \mathrm{v}\end{array}$ & $\begin{array}{l}\text { Xylose / } \\
\text { mg mL }^{-1}\end{array}$ & $\begin{array}{l}\text { Glucose } \\
\mathbf{m g ~ m}^{-1} \mathbf{~}^{-1}\end{array}$ & Author \\
\hline Rasamsonia emersonii & 4 & 60 & 5 & 1.4 & 1.24 & This study \\
\hline Thermomyces lanuginosus & 24 & 40 & 3.5 & 0.9 & NA & Ref. $^{51}$ \\
\hline Trichoderma reesei & 24 & 50 & 2 & 1.0 & 1.80 & Ref. $^{52}$ \\
\hline Aspergillus awamor & 24 & 50 & 2 & 1.3 & 3.80 & Ref. $^{53}$ \\
\hline $\begin{array}{l}\text { Botryosphaeria sp. AM01 } \\
\text { and Saccharicola sp. EJC04 }\end{array}$ & 20 & 50 & 5 & 1.7 & 3.56 & Ref. $^{50}$ \\
\hline NS 50013 by Novozymes* & 24 & 50 & 5 & 12.5 & 20.0 & Ref. $^{53}$ \\
\hline
\end{tabular}

$\mathrm{NA}=$ not analyzed.

*Commercial enzyme preparation.

\subsection{Isolation and evaluation of specific endoxylanase catalysis substrate}

The four isolated isoforms from polyacrylamide gel were evaluated by hydrolysis of synthetic substrates (pNPX and pNPG) and natural polymers (CMC, beechwood xylan and oat spelt xylan) (Tab. 3). None of the enzymes had activity against pNPG and CMC and only Xyl_B had activity against synthetic substrates. The enzymes Xyl_A, Xyl_B and Xyl_C showed high activity concerning natural polymers, whereas Xyl_D showed lower activity.
Endoxylanases from $R$. emersonii are not able to recognize glucose to hydrolyze the glycosidic bond, which limits their action to xylan constituent carbohydrates. This is observed in the GH 11 family of glycosyl hydrolases, composed exclusively of endo $\beta 1,4$ xylanases, in which no other activity was observed. They are capable of cleaving internal $\beta$ 1,4xylosidic bonds, unlike GH10 xylanases, which are also capable of cleaving $\beta$ 1,3-xylosidic and $\beta 1,4$ glycosidic bonds ${ }^{54}$. 
Table 3. Evaluation of activity of endoxylanases produced by $R$. emersonii.

\begin{tabular}{|c|c|c|c|c|c|c|c|c|}
\hline & \multicolumn{2}{|c|}{ Xyl_A } & \multicolumn{2}{|c|}{ Xyl_B } & \multicolumn{2}{|c|}{ Xyl_C } & \multicolumn{2}{|c|}{ Xyl_D } \\
\hline & $\mathrm{U} \mathrm{mL}^{-1}$ & SD & $\mathrm{U} \mathrm{mL}^{-1}$ & SD & $\mathrm{U} \mathrm{mL}^{-1}$ & SD & $\mathrm{U} \mathrm{mL}^{-1}$ & $\mathrm{SD}$ \\
\hline $4 \mathrm{mmol} \mathrm{L}^{-1} \mathrm{pNPG}$ & ND & - & ND & - & ND & - & ND & - \\
\hline $4 \mathrm{mmol} \mathrm{L}^{-1}$ pNPX & ND & - & 0.7 & 0.1 & ND & - & ND & - \\
\hline 4\% CMC & ND & - & ND & - & ND & - & ND & - \\
\hline $1 \%$ beechwood xylan & 35 & 4 & 173 & 5 & 71 & 3 & 5 & 3 \\
\hline $1 \%$ oat spelt xylan & 35 & 2 & 78 & 3 & 56 & 4 & 10 & 3 \\
\hline
\end{tabular}

Data ND: no detected activity. Average \pm standard deviation (mean values of three independent measurements).

\subsection{Thermodynamic analysis of the isolated Xyl_C}

Xylanase xyl_C displayed the highest activity when tested against xylan: $70.87 \mathrm{U} \mathrm{mL}^{-1}$ for beechwood xylan and $56.11 \mathrm{U} \mathrm{mL}^{-1}$ for oat spelt xylan. Therefore, it was chosen for the thermodynamic analysis.

The Arrhenius plot (Fig. 6), allowed calculating the optimum temperature $\left(80{ }^{\circ} \mathrm{C}\right)$ and the enzymatic activation energy $\left(26.10 \mathrm{~kJ} \mathrm{~mol}^{-1}\right)$. The first-order plot for the effect of temperature on enzyme activity (Fig. 7), was used to find the half-life and the firstorder rate of thermal inactivation $\left(k_{\mathrm{d}}\right)$. The $k_{\mathrm{d}}$ rates were used for the first-order Arrhenius plot (Fig. 8), allowing to determine the activation energy of denaturation $(E a(d))$, estimated as $99.58 \mathrm{~kJ} \mathrm{~mol}^{-1}$. The temperature coefficient decreases slightly with each increase of $10{ }^{\circ} \mathrm{C}$ (Tab. 4).

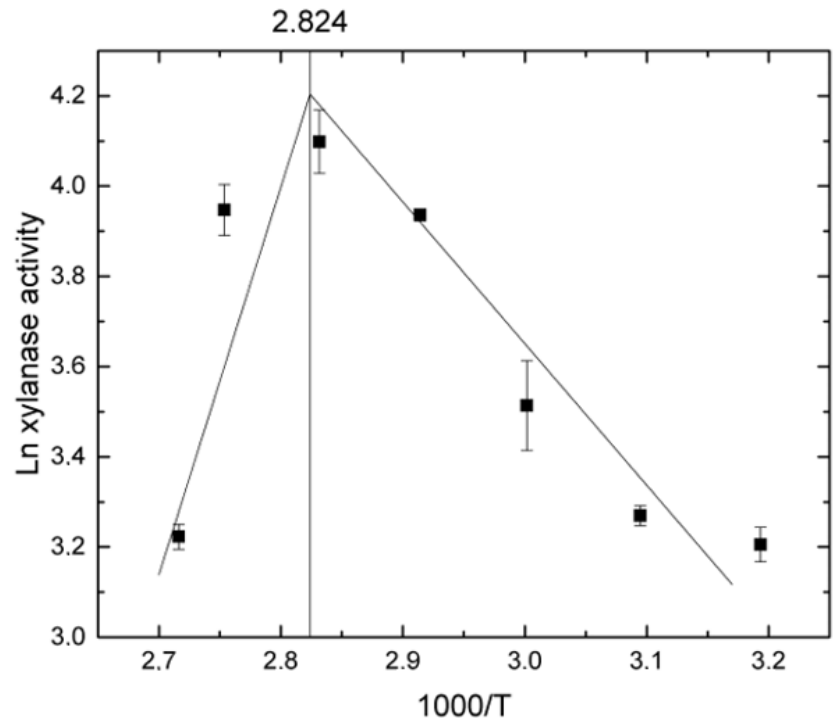

Figure 6. First-order Arrhenius plot showing the effect of temperature on activity of isolated Xyl_C produced by $R$. emersonii using beechwood xylan as substrate.

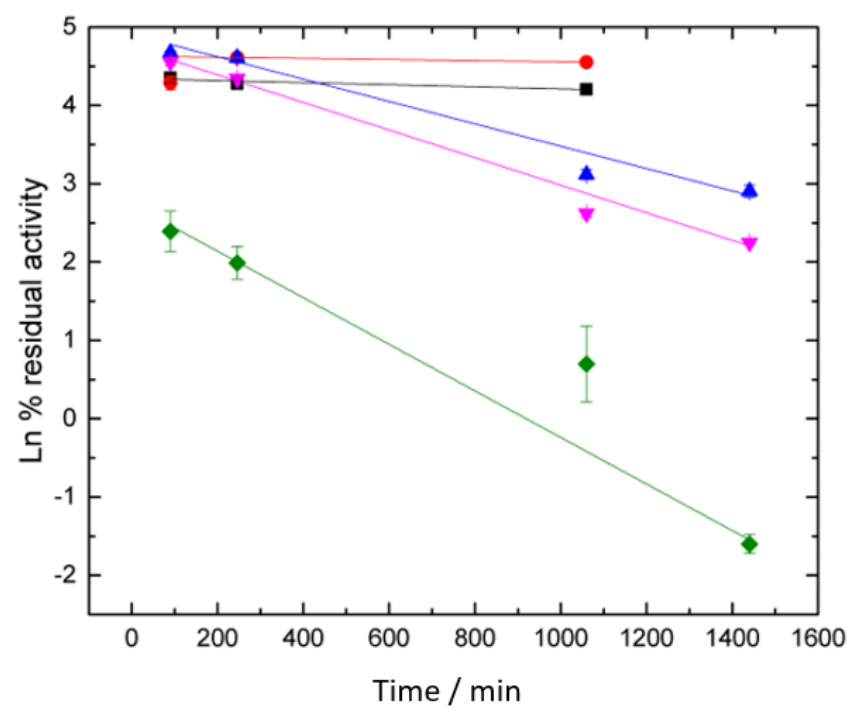

Figure 7. First-order plot for the effect of temperature on enzyme activity of isolated Xyl_C produced by $R$. emersonii using Beechwood xylan as the substrate. Samples were incubated at $50(\bullet), 60(\bullet), 70(\Delta), 80$ $(\nabla)$ and $90{ }^{\circ} \mathrm{C}(\diamond)$ for $90,246,1060$ and $1440 \mathrm{~min}$.

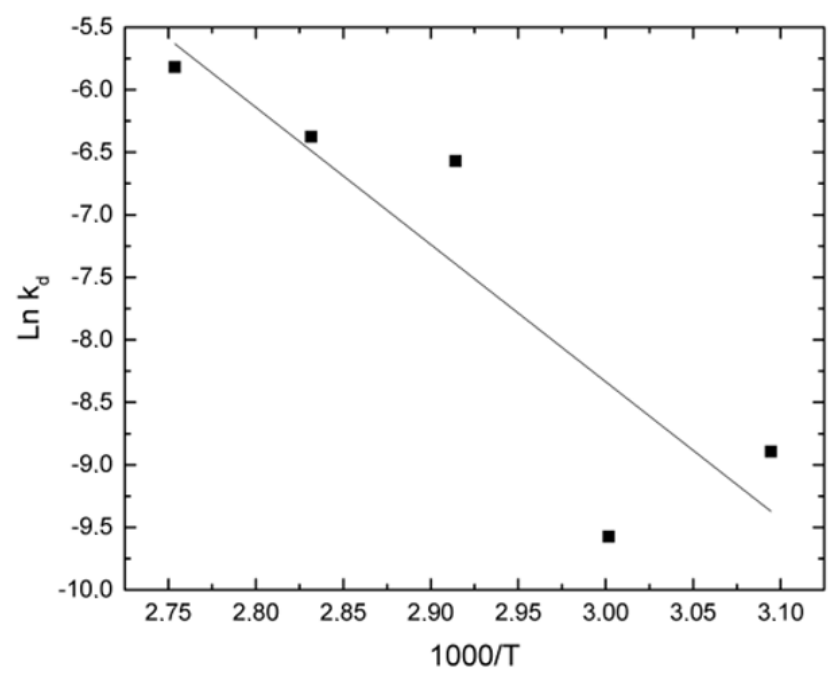

Figure 8. First-order Arrhenius plot for determination of activation energy of denaturation $\left(E_{\mathrm{a}(\mathrm{D})}\right)$ of isolated Xyl_C from $R$. emersonii. The values of $k_{\mathrm{d}}$ were taken from the slopes in Fig. 7. 
Table 4. Temperature coefficient $\left(\mathrm{Q}_{10}\right)$ from Xyl_C produced by $R$. emersonii. Values estimated based on Arrhenius plot.

\begin{tabular}{|l|c|c|}
\hline Temp. $/{ }^{\circ} \mathbf{C}$ & Temp./ K & $\mathbf{Q}_{\mathbf{1 0}}$ \\
\hline $\mathbf{5 0}$ & 313.15 & 1.35 \\
\hline $\mathbf{6 0}$ & 323.15 & 1.33 \\
\hline $\mathbf{7 0}$ & 333.15 & 1.31 \\
\hline $\mathbf{8 0}$ & 343.15 & 1.29 \\
\hline $\mathbf{9 0}$ & 353.15 & 1.27 \\
\hline $\mathbf{9 5}$ & 363.15 & 1.26 \\
\hline
\end{tabular}

Thermodynamic parameters were calculated to evaluate the temperature denaturant effect on the enzyme. Enzymes undergo thermal denaturation in two steps: the native enzyme becomes unfolded inactive enzyme when exposed to high temperature and follows to become the inactivated enzyme if the thermal exposition continues ${ }^{55}$. The first structural modification could be reversible upon cooling, while the second one is irreversible ${ }^{56}$. Table 5 shows the values for the variation of enthalpy, Gibbs free energy, entropy and the half-life time related to denaturation.

Table 5. Kinetic and thermodynamic parameters of irreversible thermal inactivation.

\begin{tabular}{|c|c|c|c|c|c|c|}
\hline Temp. $/{ }^{\circ} \mathrm{C}$ & Temp. / K & $k_{d} / \min ^{-1}$ & $t^{1} / 2 / \min$ & $\Delta H_{d} / \mathrm{kJ} \mathrm{mol}^{-1}$ & $\Delta G_{d} / \mathrm{kJ} \mathrm{mol}^{-1}$ & $\Delta \mathrm{S}_{d} / \mathrm{J} \mathrm{mol}^{-1}$ \\
\hline 50 & 323.15 & 0.00012 & 5056 & 96.9 & 114.3 & -53.8 \\
\hline 60 & 333.15 & 0.00007 & 1670 & 96.8 & 119.7 & -68.9 \\
\hline 70 & 343.15 & 0.00143 & 495 & 96.7 & 114.8 & -52.7 \\
\hline 80 & 353.15 & 0.00176 & 408 & 96.6 & 117.6 & -59.4 \\
\hline 90 & 363.15 & 0.00297 & 262 & 96.6 & 119.5 & -63.0 \\
\hline
\end{tabular}

Some enzymes have an optimal catalytic performance at high temperatures and are useful in high temperatures processes and for brief times; however, when kept at high temperatures for a long time, many enzymes do not have stability to remain active throughout the process. The half-life of Xyl_C was approximately $8 \mathrm{~h}$ at $50{ }^{\circ} \mathrm{C}, 27 \mathrm{~h}$ at $60{ }^{\circ} \mathrm{C}, 8 \mathrm{~h}$ at $70{ }^{\circ} \mathrm{C}, 6 \mathrm{~h}$ at $80{ }^{\circ} \mathrm{C}$ and $4 \mathrm{~h}$ at $90{ }^{\circ} \mathrm{C}$. The half-life at $70{ }^{\circ} \mathrm{C}$ is larger than the value reported for a mutant xylanase from Aspergillus fumigatus produced by heterologous expression at Escherichia coli BL21, $42 \mathrm{~min}$ at $70{ }^{\circ} \mathrm{C}^{57}$. Site directed mutagenesis can improve the stability significantly. Alterations of Nterminal residues of a xylanase from Penicillium janthinellum MA21601 improved the half-life 107-fold higher than the wild-type strain, increasing from $30 \mathrm{~s}$ to 53.6 min at $60{ }^{\circ} \mathrm{C}^{58}$.

High half-life values at elevated temperatures can be directly related to high melting temperatures $(\mathrm{T} m)$. The $\mathrm{T} m$ is described as the temperature at which the maximum activity drops by half. For Xyl_C, the maximum activity occurred at $80{ }^{\circ} \mathrm{C}$ and decreased to $50 \%$ of that value at $93.3^{\circ} \mathrm{C}$ (Fig. 9).

There was no significant variation in the enthalpy variation $(\Delta H \mathrm{~d})$ of thermal denaturation of Xyl_C. The enthalpy values decrease slightly with increasing temperature (Tab. 4). This behavior, together with lower entropy values, is related to enzymatic thermostability ${ }^{59}$.

Gibbs free energy values found for Xyl_C $\left(114.3 \mathrm{~kJ} \mathrm{~mol}^{-1}\right)$ at $50{ }^{\circ} \mathrm{C}$ are higher than those reported at $55{ }^{\circ} \mathrm{C}$ for wild and mutant enzymes from
Thermomyces lanuginosus: 108.5 and $112.4 \mathrm{~kJ} \mathrm{~mol}^{-1}$, respectively. The enzymes were produced by liquid cultivation with $2 \%$ of corn cobs at $45{ }^{\circ} \mathrm{C}^{59}$. These values suggest that $\mathrm{Xyl} C \mathrm{C}$ is more resistant to unfolding. Xyl_C is also more resistant than Melanocarpus albomyces xylanase in the presence of glycerol and $\mathrm{NaCl}\left(96.6 \mathrm{~kJ} \mathrm{~mol}^{-1}\right)^{60}$.

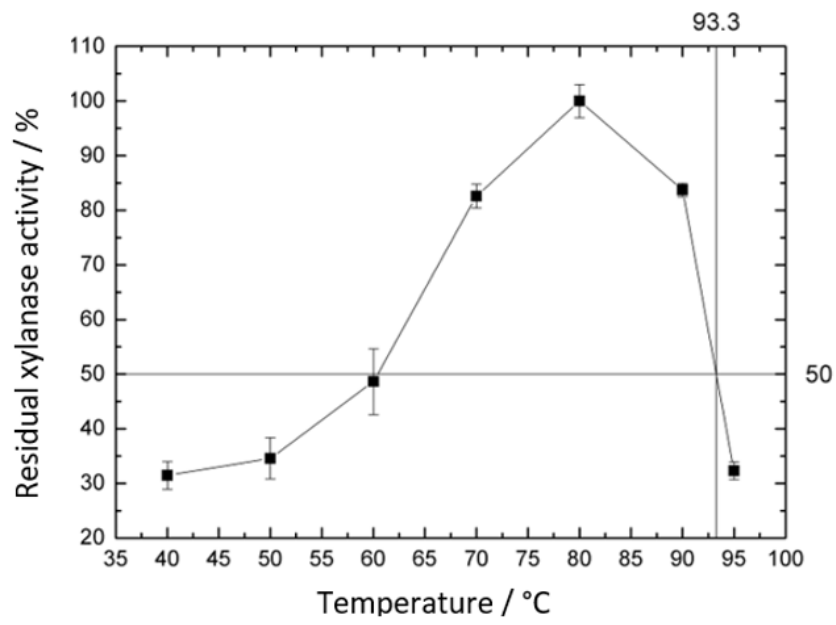

Figure 9. Determination of melting temperature $(\mathrm{T} m)$ for the isolated Xyl_C produced by $R$. emersonii. The $\mathrm{T} m$ corresponds to the temperature at which the enzyme activity drops to half of the initial activity.

Entropy is a measure of disorder in the system; the increase in disorder of the protein structure is a consequence of conformational changes in the protein. Conformational changes comprise changes in noncovalent interactions: ion-dipole, hydrogen and van 
der Waals, and in the rotational positions controlled by the secondary bond structure ${ }^{61}$. A decrease in entropy values was observed with increasing temperature for Xyl_C (Tab. 4).

Negative entropy $\left(\Delta S_{\mathrm{d}}\right)$ and positive free energy $\left(\Delta G_{\mathrm{d}}\right)$ values reveal the resistance for the denaturation reaction to occur. The increase in temperature promotes the weakening of polar interactions, and it strengthens hydrophobic interactions ${ }^{54}$ ensuring resistance of the enzyme to thermal denaturation.

\section{Conclusions}

The endoxylanases from solid state culture of $R$. emersonii present interesting properties, such as the tolerance to a wide $\mathrm{pH}$ range, as well as to the presence of diverse phenolic compounds. The enzymes also demonstrate higher activity and stability in the presence of glycerol and this is potentially relevant for industrial applications. The isolate Xyl_C has good stability against thermal denaturation, properties which can be positive on the process requiring high temperature and long periods of xylan hydrolysis. On the breakdown of the sugarcane bagasse, $R$. emersonii crude extract has provided strong hemicellulose conversion values to xylose and can be used in the process of obtaining high-value products, such as xylooligosaccharides and, for the most part, biofuels from lignocellulose residues without any additional area of cultivation.

\section{Acknowledgments}

This work was supported by grants from FAPESP, CNPq, FINEP and CAPES (Brazil). JAZ received a CAPES fellowship and JOO received financial support from Universidad Santiago de Cali, Facultad de Ciencias Básicas, Cali, Colombia.

\section{References}

[1] Abas, N., Kalair, A., Khan, N., Review of fossil fuels and future energy technologies, Futures 69 (2015) 31-49. https://doi.org/10.1016/j.futures.2015.03.003.

[2] Uihlein, A., Schebek, L., Environmental impacts of a lignocellulose feedstock biorefinery system: An assessment, Biomass and Bioenergy 33 (5) (2009) 793-802. https://doi.org/10.1016/j.biombioe.2008.12.001.

[3] Brenelli, L. B., Figueiredo, F. L., Damasio, A., Franco, T. T., Rabelo, S. C., An integrated approach to obtain xylooligosaccharides from sugarcane straw: From lab to pilot scale, Bioresource Technology $313 \quad$ (2020) 123637. https://doi.org/10.1016/j.biortech.2020.123637.

[4] Sarkar, N., Ghosh, S. K., Bannerjee, S., Aikat, K., Bioethanol production from agricultural wastes: An overview, Renewable Energy 37 (1) (2012) 19-27. https://doi.org/10.1016/j.renene.2011.06.045.

[5] Jeffries, T. W., Biodegradation of lignin-carbohydrate complexes, In: Physiology of Biodegradative Microorganisms, Ratledge, C., ed., Springer: Dordrecht, Netherlands, 1991. https://doi.org/10.1007/978-94-0113452-1_7.

[6] Lin, S. Y., Accessibility of cellulose: a critical review, Fibre Science and Technology 5 (4) (1972) 303-314. https://doi.org/10.1016/0015-0568(72)90022-X.

[7] Haltrich, D., Nidetzky, B., Kulbe, K. D., Steiner, W., Župančič, S., Production of fungal xylanases, Bioresource $\begin{array}{lllll}\text { Technology } & 58 & \text { (2) } & \text { (1996) } & 137-161 .\end{array}$ https://doi.org/10.1016/S0960-8524(96)00094-6.

[8] Bastawde, K. B., Xylan structure, microbial xylanases, and their mode of action, World Journal of Microbiology $\begin{array}{lllll}\text { and } & \text { Biotechnology } & 8 & \text { (1992) 353-368. }\end{array}$ https://doi.org/10.1007/BF01198746.

[9] Kulkarni, N., Shendye, A., Rao, M., Molecular and biotechnological aspects of xylanases, FEMS Microbiology Reviews $23 \quad$ (4) (1999) 411-456. https://doi.org/10.1111/j.1574-6976.1999.tb00407.x.

[10] Andlar, M., Rezić, T., Marđetko, N., Kracher, D., Ludwig, R., Šantek, B., Lignocellulose degradation: An overview of fungi and fungal enzymes involved in lignocellulose degradation, Engineering in Life Sciences 18 (11) (2018) 768-778. https://doi.org/10.1002/elsc.201800039.

[11] Niehaus, F., Bertoldo, C., Kähler, M., Antranikian, G., Extremophiles as a source of novel enzymes for industrial application, Applied Microbiology and Biotechnology 51 (1999) 711-729. https://doi.org/10.1007/s002530051456.

[12] Subramaniyan, S., Prema, P., Biotechnology of Microbial Xylanases: Enzymology, Molecular Biology, and Application, Critical Reviews in Biotechnology 22 (1) (2002) 33-64. https://doi.org/10.1080/07388550290789450.

[13] Lima, V. M. G., Krieger, N., Sarquis, M. I. M., Mitchell, D. A., Ramos, L. P., Fontana, J. D., Effect of nitrogen and carbon sources on lipase production by Penicillium aurantiogriseum, Food Technology and Biotechnology 41 (2003) 105-110.

[14] Cui, Y. Q., Van der Lans, R. G. J. M., Luyben, K. C. A. M., Effects of dissolved oxygen tension and mechanical forces on fungal morphology in submerged fermentation, 
Biotechnology and Bioengineering 57 (4) (2000) 409-419. https://doi.org/10.1002/(SICI)1097-

0290(19980220)57:4\%3C409::AID-BIT4\%3E3.0.CO;2-Q.

[15] Raimbault, M., Alazard, D., Culture method to study fungal growth in solid fermentation, European journal of applied microbiology and biotechnology 9 (1980) 199-209. https://doi.org/10.1007/BF00504486.

[16] Hölker, U., Höfer, M., Lenz, J., Biotechnological advantages of laboratory-scale solid-state fermentation with fungi, Applied Microbiology and Biotechnology volume 64 (2004) 175-186. https://doi.org/10.1007/s00253-003-1504-3.

[17] Bhat, M. K., Hazlewood, G. P., Enzymology and other characteristics of cellulases and xylanases, In: Enzym Farm Animal Nutrition, Bedford, M. R., Partridge, G. G., CABI Publishing: Oxfordshire, England, 2001, Ch. 11.

[18] Sun Y, Cheng J., Hydrolysis of Lignocellulosic Materials for Ethanol Production: A Review, ChemInform 34 (1) (2003). https://doi.org/10.1002/chin.200301272.

[19] Mosier, N., Wyman, C., Dale, B., Elander, R., Lee, Y. Y., Holtzapple, M., Ladisch, M., Features of promising technologies for pretreatment of lignocellulosic biomass, Bioresource Technology 96 (6) (2005) 673-686.

[20] Rosa, I. Z., Isolamento e seleção de fungos filamentosos termofílicos produtores de celulases, xilanases e celobiose desidrogenase com potencial para sacarificação do bagaço de cana-de-açúcar, master thesis, São José do Rio Preto, Universidade Estadual Paulista "Julho de Mesquita Filho" Unesp, 2014.

[21] Bailey, M. J., Biely, P., Poutanen, K., Interlaboratory testing of methods for assay of xylanase activity, Journal of

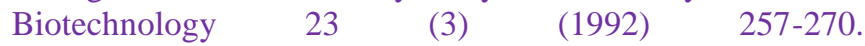
https://doi.org/10.1016/0168-1656(92)90074-J.

[22] Miller, G. L., Use of Dinitrosalicylic Acid Reagent for Determination of Reducing Sugar, Analytical Chemistry 31 (3) (1959) 426-428. https://doi.org/10.1021/ac60147a030.

[23] Perrone, O. M., Colombari, F. M., Rossi, J. S., Moretti, M. M. S., Bordignon, S. E., Nunes, C. da C. C., Gomes, E., Boscolo, M., da Silva, R., Ozonolysis combined with ultrasound as a pretreatment of sugarcane bagasse: Effect on the enzymatic saccharification and the physical and chemical characteristics of the substrate, Bioresource Technology 218 (2016) 69-76. https://doi.org/10.1016/j.biortech.2016.06.072.

[24] Liao, H., Xu, C., Tan, S., Wei, Z., Ling, N., Yu, G., Raza, W., Zhang, R., Shen, Q., Xu, Y., Production and characterization of acidophilic xylanolytic enzymes from Penicillium oxalicum GZ-2, Bioresource Technology 123 (123)

$117-124$

https://doi.org/10.1016/j.biortech.2012.07.051.
[25] Polizelli, P. P., Facchini, F. D. A., Cabral, H., BonillaRodriguez, G. O., A New Lipase Isolated from Oleaginous Seeds from Pachira aquatica (Bombacaceae), Applied Biochemistry and Biotechnology 150 (2008) 233-242. https://doi.org/10.1007/s12010-008-8145-z.

[26] Saqib, A. A. N., Farooq, A., Iqbal, M., Hassan, J. U., Hayat, U., Baig, S., A Thermostable Crude Endoglucanase Produced by Aspergillus fumigatus in a Novel Solid State Fermentation Process Using Isolated Free Water, Enzyme $\begin{array}{llll}\text { Research } & 2012 \quad \text { (2012) } & 196853 .\end{array}$ https://doi.org/10.1155/2012/196853.

[27] Saqib, A. A. N., Hassan, M., Khan, N. F., Baig, S., Thermostability of crude endoglucanase from Aspergillus fumigatus grown under solid state fermentation (SSF) and submerged fermentation (SmF), Process Biochemistry 45 (5) (2010)

641-646.

https://doi.org/10.1016/j.procbio.2009.12.011.

[28] Bonfá, E. C., Moretti, M. M. de S., Gomes, E., BonillaRodriguez, G. O., Biochemical characterization of an isolated $50 \mathrm{kDa}$ beta-glucosidase from the thermophilic fungus Myceliophthora thermophila M.7.7, Biocatalysis and Agricultural Biotechnology $13 \quad$ (2018) 311-318. https://doi.org/10.1016/j.bcab.2018.01.008.

[29] Trindade, L.V., Desagiacomo, C., Polizeli, M. de L. T. de M., Damasio, A. R. de L., Lima, A. M. F., Gomes, E., Bonilla-Rodriguez, O. G., Biochemical Characterization, Thermal Stability, and Partial Sequence of a Novel ExoPolygalacturonase from the Thermophilic Fungus Rhizomucor pusillus A13.36 Obtained by Submerged Cultivation, BioMed Research International 2016 (2016) 8653583. https://doi.org/10.1155/2016/8653583.

[30] Tuohy, M. G., Coughlan, M. P., Production of thermostable xylan-degrading enzymes by Talaromyces emersonii, Bioresource Technology 39 (2) (1992) 131-137. https://doi.org/10.1016/0960-8524(92)90131-G.

[31] Pordesimo, L. O., Hames, B. R., Sokhansanj, S., Edens, W. C., Variation in corn stover composition and energy content with crop maturity, Biomass and Bioenergy 28 (4) (2055)

366-374. https://doi.org/10.1016/j.biombioe.2004.09.003.

[32] Canilha, L., Rodrigues, R. C. L. B., Antunes, F. A. F., Chandel, A. K., Milessi, T. S. S., Felipe, M. G. A., da Silva, S. S., Bioconversion of Hemicellulose, In: Sustainable Products Sustainable Products, Sustainable Degradation of Lignocellulosic Biomass - Techniques, Applications and Commercialization, Chandel, A. K., da Silva S. S., Eds., IntechOpen: London, England, 2013. https://doi.org/10.5772/53832.

[33] Sun, X., Liu, Z., Qu, Y., Li, X., The Effects of Wheat Bran Composition on the Production of BiomassHydrolyzing Enzymes by Penicillium decumbens, Appl 
Applied Biochemistry and Biotechnology 146 (2008) 119128. https://doi.org/10.1007/s12010-007-8049-3.

[34] Nath, D., Rao, M., pH dependent conformational and structural changes of xylanase from an alkalophilic thermophilic Bacillus sp (NCIM 59), Enzyme and Microbial Technology $28 \quad(4-5) \quad$ (2001) 397-403. https://doi.org/10.1016/S0141-0229(00)00359-8.

[35] Bai, W., Zhou, C., Zhao, Y., Wang, Q., Ma, Y., Structural Insight into and Mutational Analysis of Family 11 Xylanases: Implications for Mechanisms of Higher $\mathrm{pH}$ Catalytic Adaptation, PLoS One 10 (7) (2015) e0132834. https://doi.org/10.1371/journal.pone.0132834.

[36] Viana, Y. A., Garrote Filho, M. da S., Penha-Silva, N., Estabilização de proteínas por osmólitos, Bioscience Journal 21 (2) (2005) 83-88.

[37] Bhatnagar, B. S., Bogner, R. H., Pikal, M. J., Protein Stability During Freezing: Separation of Stresses and Mechanisms of Protein Stabilization, Pharmaceutical Development and Technology 12 (5) (2007) 505-523. https://doi.org/10.1080/10837450701481157.

[38] Qu, Y., Bolen, C. L., Bolen, D. W., Osmolyte-driven contraction of a random coil protein, Proceedings of the National Academy of Sciences USA 95 (1998) 9268-9273. https://doi.org/10.1073/pnas.95.16.9268.

[39] Boukari, I., O’Donohue, M, Rémond, C., Chabbert, B., Probing a family GH11 endo- $\beta-1,4$-xylanase inhibition mechanism by phenolic compounds: Role of functional phenolic groups, Journal of Molecular Catalysis B:

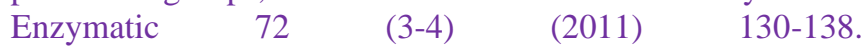
https://doi.org/10.1016/j.molcatb.2011.05.010.

[40] Haslam, E., Polyphenol-protein interactions, Biochemical Journal $139 \quad$ (1) (1974) 285-288. https://doi.org/10.1042/bj1390285.

[41] Kim, Y., Ximenes, E., Mosier, N. S., Ladisch, M. R., Soluble inhibitors/deactivators of cellulase enzymes from lignocellulosic biomass, Enzyme and Microbial Technology $48 \quad$ (4-5) (2011) 408-415. https://doi.org/10.1016/j.enzmictec.2011.01.007.

[42] Oliveira, D. M., Hoshino, É. P., Mota, T. R., Marchiosi, R., Ferrarese-Filho, O., dos Santos, W. D., Modulation of cellulase activity by lignin-related compounds, Bioresource $\begin{array}{lllll}\text { Technology } & \text { Reports } & 10 & \text { (2020) } & 100390 .\end{array}$ https://doi.org/10.1016/j.biteb.2020.100390.

[43] Freudenberg, K., Lignin: Its Constitution and Formation from p-Hydroxycinnamyl Alcohols, Science 148 (3670) (1965) 595-600.

https://doi.org/10.1126/science.148.3670.595.
[44] Mes-Hartree, M., Saddler, J. N., The nature of inhibitory materials present in pretreated lignocellulosic substrates which inhibit the enzymatic hydrolysis of cellulose, Biotechnology Letters 5 (1983) 531-536. https://doi.org/10.1007/BF01184944.

[45] Ximenes, E., Kim, Y., Mosier, N., Dien, B., Ladisch, M. Inhibition of cellulases by phenols, Enzyme and Microbial Technology 46 (3-4) (2010) 170-176.

[46] Sharma, A., Milstein, O., Vered, Y., Gressel, J., Flowers, H. M., Effects of aromatic compounds on hemicellulose-degrading enzymes in Aspergillus japonicus, Biotechnology and Bioengineering 1985;27 (8) (1985) 10951101. https://doi.org/10.1002/bit.260270802.

[47] Zhao, J., Chen, H., Stimulation of Cellulases by Small Phenolic Compounds in Pretreated Stover, Journal of Agricultural and Food Chemistry 62 (2014) 3223-3229. https://doi.org/10.1021/jf405046m.

[48] Li, H., Wu, H., Xiong, L., Chen, X., Wang, C., Qi, G., Huang, C., Guo, H., Luo, M., Liu, J., Long, M., Chen, X., The hydrolytic efficiency and synergistic action of recombinant xylan-degrading enzymes on xylan isolated from sugarcane bagasse, Carbohydrate Polymers 175 (2017) 199-206. https://doi.org/10.1016/j.carbpol.2017.07.075.

[49] Raheja, Y., Kaur, B., Falco, M., Tsang, A., Chadha, B. S., Secretome analysis of Talaromyces emersonii reveals distinct CAZymes profile and enhanced cellulase production through response surface methodology, Industrial Crops and $\begin{array}{llll}\text { Products } & 152 & \text { (2020) } & 112554 .\end{array}$ https://doi.org/10.1016/j.indcrop.2020.112554.

[50] Marques, N. P., Pereira, J. de C., Gomes E, da Silva, R., Araújo, A. R., Ferreira, H., Rodrigues, A., Dussán, K. J., Bocchini, D. A., Cellulases and xylanases production by endophytic fungi by solid state fermentation using lignocellulosic substrates and enzymatic saccharification of pretreated sugarcane bagasse, Industrial Crops and Products $122 \quad$ (2018) 66-75. https://doi.org/10.1016/j.indcrop.2018.05.022.

[51] Damaso, M. C. T., Almeida, M. S., Kurtenbach, E., Martins, O. B., Pereira Junior, N., Andrade, C. M. M. C., Albano, R. M., Optimized expression of a thermostable xylanase from Thermomyces lanuginosus in Pichia pastoris, Applied and Environmental Microbiology 69 (10) (2003) 6064-6072. https://doi.org/10.1128/AEM.69.10.60646072.2003 .

[52] Gottschalk, L. M. F., Oliveira, R. A., Bon, E. P. da S. Cellulases, xylanases, $\beta$-glucosidase and ferulic acid esterase produced by Trichoderma and Aspergillus act synergistically in the hydrolysis of sugarcane bagasse. Biochemical Engineering Journal $51 \quad(1-2) \quad$ (2010) 72-78. https://doi.org/10.1016/j.bej.2010.05.003. 
[53] Zhao, X., Song, Y., Liu, D., Enzymatic hydrolysis and simultaneous saccharification and fermentation of alkali/peracetic acid-pretreated sugarcane bagasse for ethanol and 2,3-butanediol production, Enzyme and Microbial Technology 49 (4) (2011) 413-419. https://doi.org/10.1016/j.enzmictec.2011.07.003.

[54] Pollet, A., Delcour, J. A., Courtin, C. M., Structural determinants of the substrate specificities of xylanases from different glycoside hydrolase families, Critical Reviews in

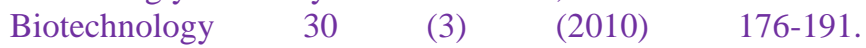
https://doi.org/10.3109/07388551003645599.

[55] Montes, F. J., Battaner, E., Catalán, J., Galán M., Kinetics and Heat-inactivation mechanisms of d-amino acid oxidase, Process Biochemistry 30 (3) (1995) 217-224. https://doi.org/10.1016/0032-9592(95)85002-3.

[56] Rashid, M. H., Siddiqui, K. S., Thermodynamic and kinetic study of stability of the native and chemically modified $\beta$-glucosidases from Aspergillus niger, Process $\begin{array}{lllll}\text { Biochemistry } & 33 & \text { (2) } & \text { (1998) } & 109-115 .\end{array}$ https://doi.org/10.1016/S0032-9592(97)00036-8.

[57] Wahab M. K. H. A., Jonet M. A., Illias R. M., Thermostability enhancement of xylanase Aspergillus fumigatus RT-1, Journal of Molecular Catalysis B: Enzymatic $2016 \quad 134$ (Part A) (2016) 154-163. https://doi.org/10.1016/j.molcatb.2016.09.020.

[58] Xiong, K., Hou, J., Jiang, Y., Li, X., Teng, C., Li, Q., Fan, G., Yang, R., Zhang, C., Mutagenesis of N-terminal residues confer thermostability on a Penicillium janthinellum MA21601 xylanase, BMC Biotechnology 19 (2019) 51. https://doi.org/10.1186/s12896-019-0541-7.

[59] Bokhari, S. A. I., Latif, F., Rajoka, M. I., Purification and characterization of xylanases from Thermomyces lanuginosus and its mutant derivative possessing novel kinetic and thermodynamic properties, World Journal of Microbiology and Biotechnology 25 (2009) 493-502. https://doi.org/10.1007/s11274-008-9915-z.

[60] Gupta, G., Sahai, V., Gupta, R. K., Thermal stability and thermodynamics of xylanase from Melanocarpus albomyces in presence of polyols and salts, BioResources 9 (4) (2014) 5801-5816. https://doi.org/10.15376/biores.9.4.5801-5816.

[61] Lumry, R., Eyring, H., Conformation Changes of Proteins, The Journal of Physical Chemistry 58 (2) (1954) 110-120. https://doi.org/10.1021/j150512a005. 